\title{
The risk of water, sanitation and hygiene on diarrhea-related infant mortality in eastern Ethiopia: a population-based nested case- control
}

\author{
Samuel Mebrahtom ${ }^{1 *}$, Alemayehu Worku² and Daniel J. Gage ${ }^{3}$
}

\begin{abstract}
Background: Diarrhea is still appeared to be as one of the leading global killers and disability-adjusted life-years lost, particularly in the infant and children. As per WHO, about $88 \%$ of diarrhea-related deaths are attributable to unsafe water, inadequate sanitation and insufficient hygiene, mainly in developing world. Thus, the main objective of this study was to find out the risk of such factors that contribute for diarrhea-related infant mortality in Eastern Ethiopia.

Methods: This study employed community based unmatched nested case-control study design in Eastern Ethiopia. The cases were infants who died from diarrheal disease while controls were those who survived their first year of life from September, 2016 to August, 2018. A total of 305 study subjects (61 cases and 244 controls) were included in the study. Infants dying from diarrhea were compared to four neighborhood controls in terms of several risk components of Water, Sanitation and Hygiene. Data were collected from mothers/care takers of infants using pre-tested structured questionnaires, and entered onto CSpro version 5.1 and transform to SPSS version 23 to analyzed potential risk factors.

Findings: Finding of this study revealed that the risk factors that found to be significantly associated with infant death from diarrhoea after adjustment for confounding variables included the age of mother with $<20$ years old $(P=0.009$, AOR: $0.01,95 \%$ Cl: $0.01,0.47)$, unsafe drinking water storage ( $P=0.013$, AOR: $0.4,95 \% \mathrm{Cl}: 0.18,0.81)$, infants in households without point-of-use water treatment practices ( $P=0.004$, AOR: 0.21,95\% Cl: 0.08, 0.61), households with unimproved sanitation ( $P=0.050$, AOR: $0.36,95 \% \mathrm{Cl}: 0.13,1.00)$, unsafe disposing of child feces $(P=0.014$, AOR: $0.34,95 \% \mathrm{Cl}: 0.15,0.81$ ), and improper management of solid waste ( $P=0.003$, AOR: $0.29,95 \% \mathrm{Cl}: 0.13,0.66)$. These exposure factors had lower risk for the contribution of infants dying from diarrhoea than those with their reference group in the study area. However, infants in households with improper management of liquid waste management showed strongly significant association which had three times more likely to occur diarrhea-related infant death ( $P=0.010$, AOR: $3.43,95 \% \mathrm{Cl}: 1.34,8.76)$. Similarly, infants whose mother/caretaker practiced hand washing with less critical time (one-two occasions) had three times greater risk to infant death from diarrhea than those who had practice more than three critical times of hand washing ( $P=0.027$, AOR: 3.04, 95\% Cl: 1.13, 8.17).
\end{abstract}

Conclusion: This study suggests that infants in households with improper management of liquid waste and hand washing practices with fewer occasions (one-two critical time) are a greater risk of getting a diarrhea-related infant

\footnotetext{
*Correspondence: samrontom@gmail.com

${ }^{1}$ Ethiopian Institute of Water Resources, Addis Ababa University, Addis

Ababa, Ethiopia

Full list of author information is available at the end of the article
} original author(s) and the source, provide a link to the Creative Commons licence, and indicate if changes were made. The images or other third party material in this article are included in the article's Creative Commons licence, unless indicated otherwise in a credit line to the material. If material is not included in the article's Creative Commons licence and your intended use is not permitted by statutory regulation or exceeds the permitted use, you will need to obtain permission directly from the copyright holder. To view a copy of this licence, visit http://creativecommons.org/licenses/by/4.0/. The Creative Commons Public Domain Dedication waiver (http://creativeco mmons.org/publicdomain/zero/1.0/) applies to the data made available in this article, unless otherwise stated in a credit line to the data. 
death. Therefore, efforts should be made to ensure intervention taking such risk factors into consideration, typically in the infantile period.

Keywords: Diarrhea-related infant mortality, Risk factors, Water, Sanitation and hygiene

\section{Background}

Diarrhea is a major cause of morbidity and mortality, in particular, among infants and children worldwide [1]. It is still appeared to be as one of the leading global killers $[2,3]$ and disability-adjusted life-years lost [4, 5]. According to the World Health Organization, more than half a million of diarrheal-related deaths reported among under five children each year in worldwide [6, 7]. In 2019, diarrhea was responsible for about $7.4 \%$ of all global causes of deaths to children $<5$ years of age [8]. Around $90 \%$ of all diarrhea-associated deaths occur in children under five years of age, particularly in lowand-middle income countries $[9,10]$.

Despite substantial reduction of the total annual number of diarrheal-related death is observed in the world among children $<5$ years over the period 1990 and 2017, the number of death remained highest in some of the world's developing countries [11]. Evidences indicated that south Asia and sub-Saharan Africa were among the highest death rates areas, where $78 \%$ of childhood diarrheal deaths occurred [12]. From all deaths, the top five countries where the most frequent diarrhea deaths occurred include: Nigeria, India, Pakistan, Democratic Republic of Congo and Ethiopia $[12,13]$. While the majority of diarrhea cases occur in developing countries, developed nations also experience a considerable burden from diarrhea [14].

Diarrhea has been shown to be one of the main causes of infant mortality in Ethiopia [8, 15], and its burden is still a serious concern [16-19]. Although the under five deaths due to diarrhea decreased from 16 to $8 \%$ between 2000 and 2016, the reduction trend of diarrheal death in this country observed to be unsteady [15]. Diarrheal disease is the fourth leading cause of infant death in Ethiopia, responsible for death rate of 136.6 deaths per 100,000 populations by the year 2019 [8]. Evidences have shown that the link between diarrheal death and the risk of unsafe water supply, inadequate sanitation, and insufficient hygiene practices are very much strong, contributing for $88 \%$ of diarrhearelated deaths [20-22]. In Ethiopia, an estimated 35.1 and $93.7 \%$ of households lack access to improved water supply and sanitation respectively and yet, rate of handwashing with soap remain low (17.6\%) [16]. The regions resided in eastern part of Ethiopia have been known as one of the area where diarrhea morbidity and mortality are observed [16]. The medical report suggests that diarrhea is among the top ten morbidity cases in the districts found in Eastern Ethiopia.

According to WHO, diarrhea is commonly defined as the passage of loose or watery stools occurring three or more times in a 24-h period, and causes death by depleting body fluids resulting in profound dehydration [23]. It can be easily treatable and preventable [22-24]. Most of diarrhoea-related deaths are appeared in small children $[25,26]$. Infants ( $<1$ year of age) is being placed at the highest death from diarrhea among children under 5 years of age [14, 27]. Diarrhea can have a harmful impact on childhood growth and cognitive development [28]. Hence, paying a particular attention to this age group will turn down a marked effect on infant mortality. There are multiple risk factors that likely to be responsible for the cause of childhood diarrhea-related mortality. Along with biological and social factors, environmental factors such as deficient in Water supply, Sanitation and Hygiene are one of the main risk factors that contribute for diarrheal death of infants [29-31], and also the leading risk factor identified in the world [23, 25, 32].

Publications that has examined on diarrheal death related risk factors were rare [30]. Indeed, many studies were conducted on under five predominantly in diarrheal morbidity [32], and studies on risk factors that makes diarrhea-related death more likely to happen particularly on infants ( $<1$ year of age group) were very much limited and has not yet been analyzed in the study area. Hence, there is need such extensive study which helps to develop better understanding for selecting strategies in reducing the death due to diarrhea. Accordingly, the main objective of this particular study was to identify the risk of drinking water supply, sanitation and hygiene components that contribute to diarrhea-related infant mortality in Eastern Ethiopia. This study assumed to be filled the existing gap and enable policy and decision makers to develop preventive strategy that can help infant survival against diarrhea.

\section{Materials and methods Study setting}

This study was conducted in six randomly selected districts in West Hararghe administrative zone of Oromia region and Zone 3 of Afar region, which are situated in Eastern part of Ethiopia. The districts include Chiro, Mieso, Gemechis and Tullo districts of West Hararghe administrative zone of Oromia while Amibara and Awash 
Fentale districts that comprised in zone 3 administration of Afar region. Based on the 2007 National Population and Housing Census of Ethiopia [33], the projected population estimate for the year 2019 to each districts; Chiro (243,151), Mieso (191,978), Gemechis $(263,615)$, Tullo (212,234), Amibara $(85,964)$ and Awash Fentale $(40,448)$. Of the total population, $3.4 \%$ are under the age of one year in the national context [33]. The study area has two main climate seasons - a dry season and a rainy season: The dry season ranges from October to February while the rainy seasons have two periods - the period from June to September is the main rainy season and some rainy weather period usually from March to May [34]. As of 2019, the health facilities available to each districts; Chiro (One hospital, 7 health centres and 39 health posts), Meiso (One hospital, 3 health centres and 33 health posts), Gemechis (6 health centres and 36 health posts), Tullo (8 health centres and 30 health posts), Amibara (one hospital, 3 health centres and 13 health posts) and Awash Fentale (2 health centres and 11 health posts). As a common, the most frequently cases observed in the districts are Acute upper respiratory tract infection, Lower respiratory infections such as pneumonia and bronchitis, Diarrheal diseases, Malaria, Urinary tract infections and skin infections. Due to inconsistency of secondary data, access coverage to improved water supply, sanitation and good hygiene practices is challenging in each districts. However, as per the expert's opinion, most of the districts population have inadequate access to improved drinking water and sanitation, and insufficient hygienic practices were still a common problem.

\section{Study design}

The study employed community based nested unmatched case-control study, which was nested from longitudinal survey conducted to identify cause of infant mortality from September, 2016 to August, 2018 in Eastern Ethiopia.

\section{Study population}

The study population (mother-infant pair) consisted of cases and controls drawn from the longitudinal survey conducted in the randomly selected study area. Cases were infants who died from diarrheal disease (all 61 cases that have been identified in the study area during the study period were included) while controls were those who survived their first year of life.

\section{Sample size determination}

The sample size was computed using Openepi version 3.03a, and calculated with the sample size for unmatched case control study. The sample size was calculated for each variable taking the result of the study conducted previously that would allow to taking the largest sample size. Accordingly, the sample size was determined based on the assumption that the proportion of latrine of the household as a risk factor for diarrhea-related infant death among the household of controls to be 15.4 and $5.93 \%$ for cases [30], two-sided significance level $(1$-alpha $)=95 \%$, Power (1-beta, \% chance of detecting) $=90$, Ratio of Unexposed to Exposed in sample $=1: 4$, to detect an odds ratio of 0.29 . Thus, the minimum sample size required for the study estimated to be 290 ( 58 cases and 232 controls). Because of many reasons of uncertainty and possible non-response, $10 \%$ were added, thus the final sample size resulted as 319 (64 cases and 255 controls).

\section{Sampling technique}

The sampling techniques for this particular study exploit all diarrheal deaths of infants, which were selected as cases while density sampling used for the control groups. The entire cases (infant died from diarrhea) that ascertained by electronics verbal autopsy were directly taken from the longitudinal survey. Infants who had survive their first year were eligible for selection as control group, which were randomly selected from the adjacent area linked to that of the infants died due to diarrhea. For each case, four neighborhood controls were randomly selected from the longitudinal survey database and compared in terms of socio-demographic and several risk components of Water, Sanitation and Hygiene.

\section{Data collection instrument and methods}

Data were collected by trained data collectors using structured and pre-tested questionnaire and conducted under closely overseen by supervisors. The questionnaire was prepared based on WHO, UNICEF and national standards as well as adopted from relevant literatures [35, 36]. This questionnaire was first developed in English, then translated into both "Amharic" and "Afan Oromoo", and back translated into English to ensure its meaning of questions is retained and checked consistency. The respondents were mothers or primary caretaker of the infants $(<1$ year of age).

\section{Data quality control}

Data quality was assured by controlling both random and systemic error. Data quality was maintained through properly designed data collection tool, and data collectors as well as supervisors recruited with the relevant educational background and language proficiency. Training was held and pre-test carried out in a community with similar characteristics. The data collection procedures developed and the collected data were reviewed 
by principal investigator. Any identified errors were discussed and immediate measure has been taken.

\section{Data management and analysis}

The collected data were entered into CSPro version 6.1 then transformed to SPSS version 23 for analysis. Descriptive statistics such as frequency distribution and cross tabulation were made to summarize the study variables. Both bivariate and multivariable conditional logistic regression was used to estimate crude and adjusted odds ratios with $95 \%$ confidence intervals for the association between risk factors and diarrhea-related infant death. Bivariate conditional logistic regression for each variable was analyzed and any risk factors that showed marked association ( $p$-value $\leq 0.25)$ were considered as candidate for multivariable logistic regression. The Hosmer-Lemeshow goodness-of-fit test was checked and indicated as this model is valid seeing that the $p$-value is greater than 0.05 . Variables that resulted $P$ value $\leq 0.05$ in the multivariable logistic regression were affirmed as significantly associated with the outcome variable (diarrhearelated infant death).

\section{Operational definitions \\ Water accessible}

People access to 251 per capita per day within $1 \mathrm{~km}$ radius from improved water supply sources for rural community [36].

\section{Households adequate water treatment at point-of-use}

Boiling, add bleach/chlorine, water filter (ceramic, sand, composite) and solar disinfection [35].

\section{Safe water storage}

Water stored in plastic, clay or metal pot narrow mouth (usually diameter of $3 \mathrm{~cm}$ or less), have a lid or secured cover and a tap (spigot), cleaned and kept cover [37].

\section{Improved sanitation}

Flush/pour toilet, Ventilated Improved Pit (VIP) latrine, simple pit latrine with slab (slab that can be cleaned), composting toilet [35].

\section{Access to hand washing facilities near to latrine}

Presence of hand washing station within $3 \mathrm{~m}$ of the latrine with water and soap/substitute.

\section{Critical time of hand washing}

Hand washing with soap or substitute at critical times (the most recommended occasions): after using latrine, after cleaning child bottom, before preparing food, before feeding child, before breastfeeding.

\section{Safe disposal of children's faeces}

Child used toilet/latrine, put/rinsed faeces into the toilet/ latrine and buried the faeces [35].

\section{Proper solid waste management}

Households dispose their wastes to waste collection tank, provide to private waste collection groups, buried and/or burn, and composting.

\section{Proper liquid waste management}

Households dispose their liquid wastes through infiltrate to the ground, cesspool (a pit dug in the ground to receive liquid waste) and dumping to municipal disposal sites.

\section{Results}

General characteristics of study subjects and respondents A total of 305 study subjects (61 cases and 244 controls) were included in the study, which yields the non-response rate 4.7 and $4.3 \%$ for case and control, respectively. Among these studied subjects, 61 were infants who died as the result of diarrheal disease (cases),and 244 were those who survived their first year of life (controls), which was nested in a longitudinal survey database (from September 2016 to August 2018) residing in Eastern Ethiopia.

\section{Socio-demographic characteristics associated with infant diarrheal death}

Of the Interviewed infants' mothers/caretakers, the mean age $( \pm S D)$ of the respondent among cases (infant who died due to diarrhea) was $26.8( \pm 3.9)$ years old and $27.8( \pm 4.5)$ for controls (infant who survived their first year of life). The majority of the infants' mothers of the cases fall within the youth age group of 20-34 (90.2\%), while it was $(82.0 \%)$ for the controls. About $44.3 \%$ of cases and $48.4 \%$ of controls had history of having borne two to four viable offspring (Parity). The mean $( \pm S D)$ family size of households with infants in the cases was $4.70( \pm 1.98)$ and $4.99( \pm 1.96)$ for controls. Majority of the study participants were married at $96.7 \%$ of cases and $98.0 \%$ of controls. Oromo ethnic group comprises the largest proportion of the study subjects (90.2\% of cases and $87.3 \%$ of controls). Muslim followers were larger in the study participants at $98.4 \%$ for cases and $88.5 \%$ for the control group. The majority of the respondents $(88.5 \%$ of cases and $74.2 \%$ of controls) were not educated. Likewise, most of the spouse of the cases (78.7\%) was uneducated as compared with the controls (65.2\%). Almost equal proportion of the cases $(90.2 \%)$ and the controls $(90.6 \%)$ were housewives by occupation. Spouse's occupational status between the 
two-study groups indicated that about (90.2\%) cases and $(85.7 \%)$ controls were found to be farmers/own farm labor. High proportion of controls (50.8\%) compared with that of cases (45.9\%) had an average household monthly income of more than and equal to 570 ETB.

The bivariate analysis between socio-demographic characteristics and diarrhea-associated infant death indicated that mothers and spouse's level of education were significantly associated with infant's diarrheal death. In this analysis, it was estimated that the infants whose mothers were not educated had less likely for risk of infant death as a result of diarrhea than those whose mothers had reached at some level of schooling $(P=0.021$, COR: $0.37,95 \%$ CI: $0.16,0.86)$. Likewise, the death of infants due to diarrhea was less likely to occur for the uneducated spouse than educated $(P=0.046$, COR: $0.51,95 \%$ CI: $0.26,0.98$ ) (see Table 1 ).

Table 1 Frequency distribution and bivariate analysis of socio-demographic characteristics with diarrhea cases and controls in Eastern Ethiopia, 2016-18

\begin{tabular}{|c|c|c|c|c|c|c|}
\hline \multirow[t]{2}{*}{ Socio-demographic Characteristics } & \multicolumn{2}{|c|}{ Case } & \multicolumn{2}{|c|}{ Control } & \multirow{2}{*}{$\begin{array}{l}\text { Crude Odds Ratio } \\
(95 \% \mathrm{Cl})\end{array}$} & \multirow[t]{2}{*}{$P$-value } \\
\hline & $\mathrm{n}$ & $\%$ & $\mathrm{n}$ & $\%$ & & \\
\hline \multicolumn{7}{|l|}{ Age of the mother } \\
\hline$<20$ Years old & 5 & 8.2 & 18 & 7.3 & $0.14(0.02,1.05)$ & 0.056 \\
\hline 20-34 Years old & 55 & 90.2 & 200 & 82.0 & $1.01(0.36,2.84)$ & 0.985 \\
\hline$\geq 35$ years old & 1 & 1.6 & 26 & 10.7 & 1 & - \\
\hline \multicolumn{7}{|l|}{ Parity } \\
\hline $1 \mathrm{st}$ & 22 & 36.0 & 72 & 29.5 & $0.97(0.46,2.06)$ & 0.939 \\
\hline 2nd-4th & 27 & 44.3 & 118 & 48.4 & $1.34(0.71,2.52)$ & 0.372 \\
\hline$\geq 5$ & 12 & 19.7 & 54 & 22.1 & 1 & - \\
\hline \multicolumn{7}{|l|}{ Household Family Size } \\
\hline$\geq 5$ & 18 & 29.5 & 91 & 37.3 & $1.42(0.77,2.61)$ & 0.258 \\
\hline$<5$ & 43 & 70.5 & 153 & 62.7 & 1 & - \\
\hline \multicolumn{7}{|l|}{ Maternal Marital Status } \\
\hline Married & 59 & 96.7 & 239 & 98.0 & $1.62(0.31,8.56)$ & 0.570 \\
\hline Unmarried & 2 & 3.3 & 5 & 2.0 & 1 & - \\
\hline \multicolumn{7}{|l|}{ Ethnicity } \\
\hline Oromo & 55 & 90.2 & 213 & 87.3 & $0.75(0.29,1.89)$ & 0.540 \\
\hline Others & 6 & 9.8 & 31 & 12.7 & 1 & - \\
\hline \multicolumn{7}{|l|}{ Religion } \\
\hline Muslim & 60 & 98.4 & 216 & 88.5 & $5.65(0.75,42.9)$ & 0.094 \\
\hline Christian & 1 & 1.6 & 28 & 11.5 & 1 & - \\
\hline \multicolumn{7}{|l|}{ Mother's level of education } \\
\hline No education & 54 & 88.5 & 181 & 74.2 & $0.37(0.16,0.86)^{*}$ & 0.021 \\
\hline Educated & 7 & 11.5 & 63 & 25.8 & 1 & - \\
\hline \multicolumn{7}{|l|}{ Spouse's level of education } \\
\hline No education & 48 & 78.7 & 159 & 65.2 & $0.51(0.26,0.98)^{*}$ & 0.046 \\
\hline Educated & 13 & 21.3 & 85 & 34.8 & 1 & - \\
\hline \multicolumn{7}{|l|}{ Mother's Occupation } \\
\hline Housewife & 55 & 90.2 & 221 & 90.6 & $1.05(0.41,2.69)$ & 0.922 \\
\hline Others & 6 & 9.8 & 23 & 9.4 & 1 & - \\
\hline \multicolumn{7}{|l|}{ Spouse's Occupation } \\
\hline Farmer/own farm labor & 55 & 90.2 & 209 & 85.7 & $0.65(0.26,1.63)$ & 0.359 \\
\hline Others & 6 & 9.8 & 35 & 14.3 & 1 & - \\
\hline \multicolumn{7}{|c|}{ Households Average Monthly Income (ETB) } \\
\hline$<570$ ETB & 33 & 54.1 & 120 & 49.2 & $0.82(0.47,1.44)$ & 0.492 \\
\hline$\geq 570 \mathrm{ETB}$ & 28 & 45.9 & 124 & 50.8 & 1 & - \\
\hline
\end{tabular}

*Risk factors significantly associated at $p$-value $\leq 0.05$ 
Environmental variables (water supply, sanitation and hygiene) associated with risk of infant death due to diarrhea

The distribution of cases and controls as well as bivariate analysis in the different categories of Water supply, Sanitation and Hygiene presented as follows:

\section{Risk of access and use of water supply associated with infant's diarrheal death}

Almost equal proportion of case (78.7\%) and control (78.3\%) group of infant's households were used improved water sources. The household's time to access water source resulted with $30 \mathrm{~min}$ or less $(65.6 \%$ of case and $62.7 \%$ of control). About $85.2 \%$ of cases and $82.0 \%$ controls fetched water within $1 \mathrm{~km}$ radius from their dwelling. Most of the infants in the households with less than 251 water consumption per capita per day among case and control group appears to be 88.5 and $75.4 \%$, respectively. The vast majority of cases $(91.8 \%)$ and controls (79.1\%) among infants in the households found with water inaccessibility (i.e households not access to at least 251 per capita per day within a distance up to $1 \mathrm{~km}$ radius). High proportion of cases $65.6 \%$ compared with that of control (40.2\%) found to have unsafe drinking water storage. Majority of controls (65.2\%) compared with case $(52.5 \%)$ reported to know at least one and more households point-of-use drinking water treatment methods. However, about $80.3 \%$ of the cases and $61.5 \%$ of controls' group have ever practiced water treatment at household's point-of-use.

In the bivariate analysis, the exposure variables that showed significant association with diarrheal-related infant death were households Water Consumption Per Capita per day with less than $25 \mathrm{l} / \mathrm{c} /$ day $(P=0.031$, COR: 0.40, 95\% CI: 0.17, 0.92), households water inaccessibility $(P=0.028$, COR: $0.34,95 \% \mathrm{CI}: 0.13,0.89)$, households with unsafe drinking water storage $(P<0.001$, COR: 0.35 , $95 \%$ CI: $0.20,0.63)$, households reported as did not practices water treatment at Point-of-use $(P=0.007, C O R$ : $0.39,95 \%$ CI: $0.20,0.77)$. However, all of these variables as the risk were less likely to be occurred infant death due to diarrhea (see Table 2).

\section{Risk of sanitation associated with infant's diarrheal death} About $65.6 \%$ of the cases and $76.2 \%$ of controls infants in the households had their own latrine. Nearly a similar proportion of households in cases and controls have practiced open defecation (21.3\% for cases and $20.1 \%$ for controls). The household's latrine utilization appears to be $60.7 \%$ in cases and $71.3 \%$ in the control group. Less than half of the study subject (39.3\%) in cases and about $49.6 \%$ in controls have found with cleaned latrines. Hand washing facilities near to latrine comprises the less proportion in case (18\%) than in the control (50\%). The majority of cases (83.6\%) compared with controls (66.4\%) in the households found with unimproved sanitation status. Unsafe disposes of child feces in the households appear in large in cases $(70.5 \%)$ than in control (39.8\%). About $54.1 \%$ of cases and $79.9 \%$ of controls in the households dispose solid wastes in improper way. Majority of cases (82.0\%) as compared with controls $(57.4 \%)$ found with unsafe disposal of liquid wastes by the households.

In the bivariate analysis, households with unimproved sanitation $(P=0.011$, COR: $0.39,95 \% \mathrm{CI}: 0.19,0.80)$, households with unsafe disposing of child feces $(P<0.001$, COR: 0.28, 95\% CI: 0.15, 0.51), households with improper management of solid waste $(P<0.001, \mathrm{COR}$ : $0.21,95 \% \mathrm{CI}$ : $0.12,0.39)$ were less likely to occur infant death as a result of diarrhea. However, infants in the households who disposed liquid waste unsafely were 3.4 times more likely at risk of diarrheal-associated infant death as compared to infants in the households who properly managed it $(P=0.001$, COR: $3.38,95 \%$ CI: $1.68,6.80)$ (see Table 3$)$.

\section{Risk of hygiene associated with infant's diarrheal death}

The result showed that about $29.5 \%$ in case group and $9.8 \%$ in controls of the respondents reported as did not washing their hands at any critical time. Handwashing practices was scored less than three critical time of Hand washing, which shows almost similar proportion in both comparative groups (59.0\% for cases and 59.5\% for controls). The vast majority of cases (83.6\%) compared with controls (32.0\%) of households reported not used any agents during handwashing.

In the bivariate analysis, infants in the households did not practice hand washing in any critical time at all were less likely to occur infant diarrheal death as compared to households practiced three and more critical time of Hand Washing $(P=0.025$, COR: $0.38,95 \%$ CI: $0.16,0.89)$. In contrary, infants in the households practiced less than three critical time of hand washing was three times more likely to have diarrhea related death than households practiced three and more critical time of Hand Washing $(P=0.002$, COR: 3.02 , 95\% CI: $1.48,6.16)$. The occurrence of diarrhea death among infant's households who did not use agents (water with soap or ash/abrasives) during hand washing was two times higher than those who used agents $(P=0.030$, COR: $1.91,95 \% \mathrm{CI}: 1.07$, 3.43) (see Table 4).

\section{Multivariable's conditional logistic regression analysis}

In the multivariable conditional logistic regression, the risk factors that were significantly associated with infant diarrheal death identified includes age of mother with $<20$ years old, unsafe drinking water storage, infants in households without point-of-use water treatment 
Table 2 Frequency distribution and bivariate analysis of drinking water access and use with diarrhea cases and controls in Eastern Ethiopia, 2016-18

\begin{tabular}{|c|c|c|c|c|c|c|}
\hline \multirow[t]{2}{*}{ Water Supply Characteristics } & \multicolumn{2}{|c|}{ Case } & \multicolumn{2}{|c|}{ Control } & \multirow{2}{*}{$\begin{array}{l}\text { Crude Odds Ratio } \\
(95 \% \mathrm{Cl})\end{array}$} & \multirow[t]{2}{*}{$P$-value } \\
\hline & $\mathbf{n}$ & $\%$ & $\mathbf{n}$ & $\%$ & & \\
\hline \multicolumn{7}{|l|}{ Households Water Source } \\
\hline Unimproved & 13 & 21.3 & 53 & 21.7 & $1.03(0.52,2.03)$ & 0.945 \\
\hline Improved & 48 & 78.7 & 191 & 78.3 & 1 & - \\
\hline \multicolumn{7}{|l|}{ Time to access water } \\
\hline Above $30 \mathrm{~min}$ & 21 & 34.4 & 91 & 37.3 & $1.13(0.63,2.04)$ & 0.678 \\
\hline 30 min or less & 40 & 65.6 & 153 & 62.7 & 1 & - \\
\hline \multicolumn{7}{|l|}{ Distance to access water } \\
\hline Above $1 \mathrm{~km}$ radius & 9 & 14.8 & 44 & 18.0 & $1.27(0.58,2.77)$ & 0.546 \\
\hline Within $1 \mathrm{~km}$ radius & 52 & 85.2 & 200 & 82.0 & 1 & - \\
\hline \multicolumn{7}{|c|}{ Water quantity (Water Consumption Per Capita per day) } \\
\hline Less than $25 \mathrm{l} / \mathrm{c} /$ day & 54 & 88.5 & 184 & 75.4 & $0.40(0.17,0.92)^{*}$ & 0.031 \\
\hline $25 \mathrm{l} / \mathrm{c} /$ day and above & 7 & 11.5 & 60 & 24.6 & 1 & - \\
\hline \multicolumn{7}{|l|}{ Households Water Accessibility ${ }^{a}$} \\
\hline Not accessible & 56 & 91.8 & 193 & 79.1 & $0.34(0.13,0.89)^{*}$ & 0.028 \\
\hline Accessible & 5 & 8.2 & 51 & 20.9 & 1 & - \\
\hline \multicolumn{7}{|l|}{ Drinking Water Storage } \\
\hline Unsafe & 40 & 65.6 & 98 & 40.2 & $0.35(0.20,0.63)^{* *}$ & 0.000 \\
\hline Safe & 21 & 34.4 & 146 & 59.8 & 1 & - \\
\hline \multicolumn{7}{|c|}{ Household Point-of-use water treatment knowledge } \\
\hline Do not know at all & 29 & 47.5 & 85 & 34.8 & $1.70(0.96,2.99)$ & 0.068 \\
\hline Knows at least 1 and more methods & 32 & 52.5 & 159 & 65.2 & 1 & - \\
\hline \multicolumn{7}{|c|}{ Household Point-of-use water treatment Practices } \\
\hline Do not treat & 49 & 80.3 & 150 & 61.5 & $0.39(0.20,0.77)^{*}$ & 0.007 \\
\hline Treat Water & 12 & 19.7 & 94 & 38.5 & 1 & - \\
\hline
\end{tabular}

*Risk factors significantly associated at $p$-value $\leq 0.05$

**Risk factors significantly associated at $p$-value $<0.001$

${ }^{\text {a }}$ Water Accessible: Households access to at least $25 \mathrm{I}$ per capita per day within $1 \mathrm{~km}$ from improved water supply sources

practices, households with unimproved sanitation status, households with unsafe disposing of child feces, households with improper management of solid and liquid waste, households with lesser hand washing practices at critical time.

In this analysis, infants whose age of mother being lower than 20years old had significant relationship with less likely to occur infant death due to diarrhea as compared to those reference group of age $\geq 35$ years $(P=0.009$, AOR: $0.01,95 \%$ CI: 0.01, 0.47). However, mother's religious status, mothers and spouse's level of education did not show statistically significant association with infant's diarrheal death, particularly after adjustment.

Infants in households with unsafe drinking water storage and households treating their drinking water at point-of-use showed significant association with infant diarrheal death. However, households exposed to unsafe drinking water storage were less likely to be at risk of infant death from diarrhoea as compared to that of safe drinking water storage $(P=0.013$, AOR: 0.4 , 95\% CI: 0.18, 0.81). Similarly, those households who did not treat their drinking water at point-of-use were less likely to be at risk of having infant death from diarrheal than those treated their drinking water $(P=0.004$, AOR: 0.21, 95\% CI: 0.08, 0.61).

The occurrence of diarrheal death among infants in households with unimproved sanitation status was less likely than households with those improved sanitation ( $P=0.050$, AOR: $0.36,95 \%$ CI: $0.13,1.00)$. Compared to households with the safe disposing of child faeces, those disposing unsafely were found with an increased odds of infant death due to diarrhoea $(P=0.014$, AOR: $0.34,95 \%$ CI: $0.15,0.81)$. Infant diarrheal death were less likely to happen in the households disposing solid wastes improper than those properly managed $(P=0.003$, AOR: $0.29,95 \%$ CI: $0.13,0.66$ ). 
Table 3 Frequency distribution and bivariate analysis of sanitation with diarrhea cases and controls in Eastern Ethiopia, 2016-18

\begin{tabular}{|c|c|c|c|c|c|c|}
\hline \multirow[t]{2}{*}{ Sanitation Characteristics } & \multicolumn{2}{|c|}{ Case } & \multicolumn{2}{|c|}{ Control } & \multirow{2}{*}{$\begin{array}{l}\text { Crude Odds Ratio } \\
(95 \% \mathrm{Cl})\end{array}$} & \multirow[t]{2}{*}{$P$-value } \\
\hline & $\mathbf{n}$ & $\%$ & $\mathbf{n}$ & $\%$ & & \\
\hline \multicolumn{7}{|l|}{ Latrine Ownership } \\
\hline No latrine & 21 & 34.4 & 58 & 23.8 & $0.67(0.37,1.22)$ & 0.188 \\
\hline Have Latrine & 40 & 65.6 & 186 & 76.2 & 1 & - \\
\hline \multicolumn{7}{|l|}{ Open Defecation Practices } \\
\hline Yes & 13 & 21.3 & 49 & 20.1 & $0.93(0.47,1.85)$ & 0.831 \\
\hline No & 48 & 78.7 & 195 & 79.9 & 1 & - \\
\hline \multicolumn{7}{|l|}{ Household Latrine Utilization } \\
\hline No & 24 & 39.3 & 70 & 28.7 & $0.62(0.35,1.11)$ & 0.109 \\
\hline Yes & 37 & 60.7 & 174 & 71.3 & 1 & - \\
\hline \multicolumn{7}{|l|}{ Household Latrine Cleanness } \\
\hline No & 18 & 29.5 & 64 & 26.2 & $1.15(0.55,2.39)$ & 0.718 \\
\hline Yes & 24 & 39.3 & 121 & 49.6 & 1 & - \\
\hline Not applicable & 19 & 31.2 & 59 & 24.2 & & \\
\hline \multicolumn{7}{|c|}{ Hand washing Facility near to latrine } \\
\hline No & 31 & 50.8 & 63 & 25.8 & $0.65(0.33,1.28)$ & 0.217 \\
\hline Yes & 11 & 18.0 & 122 & 50.0 & 1 & - \\
\hline Not applicable & 19 & 31.2 & 59 & 24.2 & & \\
\hline \multicolumn{7}{|l|}{ Sanitation Status } \\
\hline Unimproved sanitation & 51 & 83.6 & 162 & 66.4 & $0.39(0.19,0.80)^{*}$ & 0.011 \\
\hline Improved sanitation & 10 & 16.4 & 82 & 33.6 & 1 & - \\
\hline \multicolumn{7}{|c|}{ Households Disposing of Child feces } \\
\hline Unsafe & 43 & 70.5 & 97 & 39.8 & $0.28(0.15,0.51)^{* *}$ & 0.000 \\
\hline Safe & 18 & 29.5 & 147 & 60.2 & 1 & - \\
\hline \multicolumn{7}{|l|}{ Solid waste Management } \\
\hline Improper management & 33 & 54.1 & 195 & 79.9 & $0.21(0.12,0.39)^{*}$ & 0.000 \\
\hline Proper management & 28 & 45.9 & 49 & 20.1 & 1 & - \\
\hline \multicolumn{7}{|l|}{ Liquid waste Management } \\
\hline Improper management & 50 & 82.0 & 140 & 57.4 & $3.38(1.68,6.80)^{*}$ & 0.001 \\
\hline Proper management & 11 & 18.0 & 104 & 42.6 & 1 & - \\
\hline
\end{tabular}

${ }^{*}$ Risk factors significantly associated at $p$-value $\leq 0.05$

**Risk factors significantly associated at $p$-value $<0.001$

Table 4 Frequency distribution and bivariate analysis of hygiene characteristics with diarrhea cases and controls in Eastern Ethiopia, 2016-18

\begin{tabular}{|c|c|c|c|c|c|c|}
\hline \multirow[t]{2}{*}{ Hygiene Characteristics } & \multicolumn{2}{|c|}{ Case } & \multicolumn{2}{|c|}{ Control } & \multirow{2}{*}{$\begin{array}{l}\text { Crude Odds Ratio } \\
(95 \% \mathrm{Cl})\end{array}$} & \multirow[t]{2}{*}{$P$-value } \\
\hline & $\mathbf{n}$ & $\%$ & $\mathbf{n}$ & $\%$ & & \\
\hline \multicolumn{7}{|l|}{ Critical Time of Hand washing Practices } \\
\hline Do not practiced hand washing in any critical time & 18 & 29.5 & 24 & 9.8 & $0.38(0.16,0.89)^{*}$ & 0.025 \\
\hline Practiced less than three critical time of Hand washing & 36 & 59.0 & 145 & 59.5 & $3.02(1.48,6.16)^{*}$ & 0.002 \\
\hline Practiced 3 and more critical time of Hand Washing & 7 & 11.5 & 75 & 30.7 & 1 & - \\
\hline \multicolumn{7}{|l|}{ Agents used during Hand washing } \\
\hline Not used any agents & 51 & 83.6 & 78 & 32.0 & $1.91(1.07,3.43)^{*}$ & 0.030 \\
\hline Used (water + soap or ash/abrasives) & 10 & 16.4 & 166 & 68.0 & 1 & - \\
\hline
\end{tabular}

*Risk factors significantly associated at $p$-value $\leq 0.05$ 
Households with improper management of liquid waste management found with strong association with more than three times more likely to occur diarrhea-associated infant death as compared to those with proper liquid waste management $(P=0.010$, AOR: $3.43,95 \% \mathrm{CI}: 1.34$, 8.76). Infants whose mother/caretaker practiced hand washing with less critical time was three times greater risk to infant death from diarrhea than those who had practice more than three critical times of hand washing $(P=0.027$, AOR: 3.04, 95\% CI: 1.13, 8.17) (see Table 5).

\section{Discussion}

The present study has attempted to look for possible contributing risk factors for diarrheal-related infant death, predominantly, on Water supply, Sanitation and Hygiene. Although several risk factors were significantly associated with infant's diarrheal death in the bivariate analysis, some considerable factors that could predispose infants to death were identified after adjusting for confounders. These factors included age of mother with $<20$ years old, unsafe drinking water storage, infants in households without point-of-use water treatment practices, unimproved sanitation, unsafe disposing of child feces, households with improper management of solid and liquid waste and households with lesser hand washing practices at critical time.

In our study, infants whose age of mother being lower than 20 years old had significant association with the lower odds of infant's diarrheal death occurrence as compared to the reference group (age $\geq 35$ years). Regardless of the magnitude of risk, this finding is consistence with a case-control study conducted elsewhere, which reported that those infant's mother with lower maternal age were significantly associated with the risk of diarrhea-associated infant death, particularly among those with normal birth weight [38]. On the other hand, the same study indicated that older maternal age led to a higher chance of diarrhea death among infants with low birth weight. A number of studies have found that lower maternal age tend to have higher risk of mortality in children [39, 40]. This circumstance might be attributed to social and reproductive immaturity. The further likely explanation to this observation is that older mothers are more experienced in childcare and hence there is a possibility in reducing diarrhea-related incidence and death. The lower chance of diarrhea death in infant with younger mother in our study might be the influence of infant biological characteristics such as birth weight or other factors in this maternal age category, which needs further study.

Infants in households with unsafe drinking water storage had significant association with the lower chance of having infant deaths caused by diarrhea. This could be attributed to the unhygienic handling and storage of drinking water that existed in the cases group due to lack of proper and sufficient information on water handling. A study in Benin found that safe water storage had significantly associated with the reduction of diarrhea [41], which in turn lower the risk of death. The national study highlighted that storage water quality issues are a great public health concern in rural Ethiopia [42]. Our study also revealed that death risk of infant diarrhea were significant association with households without point-ofuse water treatment practices, which tend to contrary with that of earlier study conducted in southern Brazil [30]. This might be explained by the very small differences among the comparison groups in the household's water treatment practices. However, other studies suggested as strong significant impact of household water treatment on child survival [43-45]. It is evident that point-of-use water treatment improves the quality of drinking-water by avoiding cross-contamination and prevent diarrheal disease $[46,47]$, which could considerably reduce risk of mortality [45]. It can be seen from the report that pointof-use water treatment is not widely practiced in Ethiopia [16], posing a health risk of children.

Access to unimproved sanitation has been found to be significantly associated, which had lower odds of diarrhea-related infant mortality as observed in this study. This finding has similarity with another study [48], which designated as improved sanitation significantly associated with lower mortality. Regardless of the association strength, our finding underpins the conclusion made by different studies [31, 48, 49], which indicated as improved sanitation significantly higher association with the reduction of infant mortality. Evidence from the risks quantification study indicated that those countries responsible for the largest declined (13.3\%) in the diarrhea mortality rate were reduction in exposure to unsafe sanitation in children [50]. Another study in Egypt also found sanitation to have a more pronounced impact on infants and childhood risk of death from all causes [51]. It can be enlightening that; improved sanitation is fully saved, as it effectively prevents exposure to fecal matters which possibly decrease a major cause of child morbidity and mortality.

Our analyses have been also found that unsafe disposing of child feces had significantly lower risk of infant's diarrheal death than those households disposing their child feces safely. This observable low risk in the study area might be due to small differences among the two comparison groups on having information and practices of mother/caregivers on save disposal of child feces. Several studies have reported the significant effect of child feces disposal and childhood diarrhea morbidity in Ethiopia [52-54] and elsewhere [55], which could contribute to childhood mortality. Reports indicated that most of the 
Table 5 Bivariate and multivariable conditional logistic regression for the risk factors associated with diarrhea-related cases and controls in Eastern Ethiopia, 2016-18

\begin{tabular}{|c|c|c|c|c|c|c|}
\hline \multirow[t]{2}{*}{ Variables } & \multicolumn{2}{|c|}{ Case } & \multicolumn{2}{|c|}{ Control } & \multicolumn{2}{|c|}{ Odds Ratio $(95 \% \mathrm{Cl})$} \\
\hline & $\mathrm{n}$ & $\%$ & $\mathbf{n}$ & $\%$ & Crude & Adjusted \\
\hline \multicolumn{7}{|l|}{ Age of the mother } \\
\hline$<20$ Years old & 5 & 8.2 & 18 & 7.3 & $0.14(0.02,1.05)$ & $0.05(0.01,0.47)^{*}$ \\
\hline 20-34Years old & 55 & 90.2 & 200 & 82.0 & $1.01(0.36,2.84)$ & $1.59(0.37,6.75)$ \\
\hline$\geq 35$ years old & 1 & 1.6 & 26 & 10.7 & 1 & 1 \\
\hline \multicolumn{7}{|l|}{ Religion } \\
\hline Muslim & 60 & 98.4 & 216 & 88.5 & $5.65(0.75,42.9)$ & $1.00(0.11,9.47)$ \\
\hline Christian & 1 & 1.6 & 28 & 11.5 & 1 & 1 \\
\hline \multicolumn{7}{|l|}{ Mother's level of education } \\
\hline No education & 54 & 88.5 & 181 & 74.2 & $0.37(0.16,0.86)^{*}$ & $0.50(0.12,2.15)$ \\
\hline Educated at some level & 7 & 11.5 & 63 & 25.8 & 1 & 1 \\
\hline \multicolumn{7}{|l|}{ Spouse's level of education } \\
\hline No education & 48 & 78.7 & 159 & 65.2 & $0.51(0.26,0.98)^{*}$ & $0.72(0.21,2.44)$ \\
\hline Educated at Some level of schooling & 13 & 21.3 & 85 & 34.8 & 1 & 1 \\
\hline \multicolumn{7}{|c|}{ Water quantity (Water Consumption Per Capita per day) } \\
\hline Less than $25 \mathrm{l} / \mathrm{c} /$ day & 54 & 88.5 & 184 & 75.4 & $0.40(0.17,0.92)^{*}$ & $0.21(0.03,1.69)$ \\
\hline $25 \mathrm{I} / \mathrm{c} /$ day and above & 7 & 11.5 & 60 & 24.6 & 1 & 1 \\
\hline \multicolumn{7}{|l|}{ Households Water Accessibility } \\
\hline Not accessible & 56 & 91.8 & 193 & 79.1 & $0.34(0.13,0.89)^{*}$ & $1.04(0.10,10.6)$ \\
\hline Accessible & 5 & 8.2 & 51 & 20.9 & 1 & 1 \\
\hline \multicolumn{7}{|l|}{ Drinking Water Storage } \\
\hline Unsafe & 40 & 65.6 & 98 & 40.2 & $0.35(0.20,0.63)^{* *}$ & $0.38(0.18,0.81)^{*}$ \\
\hline Safe & 21 & 34.4 & 146 & 59.8 & 1 & 1 \\
\hline \multicolumn{7}{|c|}{ Household Point-of-use water treatment knowledge } \\
\hline Do not know at all & 29 & 47.5 & 85 & 34.8 & $1.70(0.96,2.99)$ & $1.16(0.45,2.97)$ \\
\hline Knows at least 1 and more methods & 32 & 52.5 & 159 & 65.2 & 1 & 1 \\
\hline \multicolumn{7}{|c|}{ Household Point-of-use water treatment Practices } \\
\hline Do not treat & 49 & 80.3 & 150 & 61.5 & $0.39(0.20,0.77)^{*}$ & $0.21(0.08,0.61)^{*}$ \\
\hline Treat Water & 12 & 19.7 & 94 & 38.5 & 1 & 1 \\
\hline \multicolumn{7}{|l|}{ Latrine Ownership } \\
\hline No latrine & 21 & 34.4 & 58 & 23.8 & $0.67(0.37,1.22)$ & $1.47(0.18,11.8)$ \\
\hline Have Latrine & 40 & 65.6 & 186 & 76.2 & 1 & 1 \\
\hline \multicolumn{7}{|l|}{ Household Latrine Utilization } \\
\hline No & 24 & 39.3 & 70 & 28.7 & $0.62(0.35,1.11)$ & $0.26(0.04,1.69)$ \\
\hline Yes & 37 & 60.7 & 174 & 71.3 & 1 & 1 \\
\hline \multicolumn{7}{|l|}{ Hand washing Facility near to latrine } \\
\hline No & 31 & 50.8 & 63 & 25.8 & $0.65(0.33,1.28)$ & $0.15(0.01,2.36)$ \\
\hline Yes & 11 & 18.0 & 122 & 50.0 & 1 & 1 \\
\hline \multicolumn{7}{|l|}{ Sanitation Status } \\
\hline Unimproved sanitation & 51 & 83.6 & 162 & 66.4 & $0.39(0.19,0.80)^{*}$ & $0.36(0.13,1.00)^{*}$ \\
\hline Improved sanitation & 10 & 16.4 & 82 & 33.6 & 1 & 1 \\
\hline \multicolumn{7}{|l|}{ Households Disposing of Child feces } \\
\hline Unsafe & 43 & 70.5 & 97 & 39.8 & $0.28(0.15,0.51)^{* *}$ & $0.34(0.15,0.81)^{*}$ \\
\hline Safe & 18 & 29.5 & 147 & 60.2 & 1 & 1 \\
\hline \multicolumn{7}{|l|}{ Solid Waste Management } \\
\hline Improper management & 33 & 54.1 & 195 & 79.9 & $0.21(0.12,0.39)^{*}$ & $0.29(0.13,0.66)^{*}$ \\
\hline Proper management & 28 & 45.9 & 49 & 20.1 & 1 & 1 \\
\hline
\end{tabular}


Table 5 (continued)

\begin{tabular}{|c|c|c|c|c|c|c|}
\hline \multirow[t]{2}{*}{ Variables } & \multicolumn{2}{|c|}{ Case } & \multicolumn{2}{|c|}{ Control } & \multicolumn{2}{|c|}{ Odds Ratio $(95 \% \mathrm{Cl})$} \\
\hline & $\mathbf{n}$ & $\%$ & $\mathbf{n}$ & $\%$ & Crude & Adjusted \\
\hline \multicolumn{7}{|l|}{ Liquid Waste Management } \\
\hline Improper management & 50 & 82.0 & 140 & 57.4 & $3.38(1.68,6.80)^{*}$ & $3.43(1.34,8.76)^{*}$ \\
\hline Proper management & 11 & 18.0 & 104 & 42.6 & 1 & 1 \\
\hline \multicolumn{7}{|l|}{ Critical Time of Hand washing Practices } \\
\hline Do not practiced in any critical time & 18 & 29.5 & 24 & 9.8 & $0.38(0.16,0.89)^{*}$ & $0.64(0.22,1.87)$ \\
\hline Practiced less than three critical times & 36 & 59.0 & 145 & 59.5 & $3.02(1.48,6.16)^{*}$ & $3.04(1.13,8.17)^{*}$ \\
\hline Practiced in 3 and more critical time & 7 & 11.5 & 75 & 30.7 & 1 & 1 \\
\hline \multicolumn{7}{|l|}{ Agents used during Hand washing } \\
\hline Not used any agents & 51 & 83.6 & 78 & 32.0 & $1.91(1.07,3.43)^{*}$ & $1.92(0.86,4.29)$ \\
\hline Used (water + soap or ash/abrasives) & 10 & 16.4 & 166 & 68.0 & 1 & 1 \\
\hline
\end{tabular}

*Risk factors significantly associated at $p$-value $\leq 0.05$

**Risk factors significantly associated at $p$-value $<0.001$

households in high-mortality countries dispose of children's feces in unsafe manner [56]. It is recognized that, children feces are more dangerous sources of fecal contamination in the household environment, and many cultures however consider the stools of infants are harmless $[35,57]$. The findings further indicated that improper management of solid wastes had significantly lower change of infant death due to diarrhea. A number of studies showed that children in households without proper waste collection practices suffer significantly higher rates of diarrhea $[18,58,59]$, which are among the main causes of childhood deaths [60]. This is due to the fact that improper disposing of domestic solid waste could be one of the suitable sites for spread of pathogens that can leads to children's morbidity and followed by mortality.

This study provides notable evidence that improper management of household's liquid wastes had a positive influence with greater magnitude in infant's death from diarrhea. The risk of death from diarrhea was more than three times higher in infants living in the households with improper liquid waste disposal than in those disposed in proper way. Reliance on scientific explanation, this might be attributed to the potential source of breading sites for flies which can carry enteric pathogens and mediate a route to contaminate children's water and food. This result agrees with the general sense that unsafe environment places puts children at risk of death [61]. The strong significant differences observed in this study might be attribute to households were not well aware with the effect of domestic liquid waste disposal on health outcome of children.

Despite the fact of human hands is one of the main vehicles for transmitting diarrhea disease, the role of poor handwashing practices at critical time as a risk factor had strong relationship with infant death from diarrhea in the study area. Our study demonstrated that those self-reported household's practiced handwashing in less occasions (One to two critical times') increases risk of infant deaths from diarrhea by 3-fold greater compared with those washed their hands at three and more critical times. Regardless of its magnitude, different studies indicated the significant link between handwashing practices and diarrhea morbidity and mortality [62-64]. The handwashing practices at critical time mainly in mothers of children is poor according to inland study [65]. Evidences indicated that handwashing at critical times reduce diarrhea rated by almost $40 \%$ [66], which could be resulted significant reduction in mortality.

\section{Strength and limitation}

The strengths of this study include as it used nested casecontrol study design which is valid and efficient design and can minimized both selection and recall bias. Despite such studies is available insufficiently at population level, in particular, this study could provide useful information for building evidence based health policy, better insights in planning the best solutions, and generate ideas for further research.

This study has limitations as respondents might not give their exact observable fact towards some given questions, which leads to social desirability biases. This could be minimized by providing training to data collectors and conducted pre-test before actual data collection launched. A very shortage of previous similar studies was made comparison difficult.

\section{Conclusion}

In conclusion, this study finding pointed out the risk factors that were statistically significant associated with less likely to occurred diarrhea-related infant death include; 
age of mother with $<20$ years old, unsafe drinking water storage, infants in households without point-of-use water treatment practices, households with unimproved sanitation status, unsafe disposing of child feces and improper management of solid waste. On the other hand, households with improper management of liquid waste and household's practiced handwashing in fewer occasions (One to two critical times') were significantly associated with more likely to contribute lost of infant life due to diarrhea. The significant link of such risk factors could be one of the reasons for the contribution of uppermost death level of infants as the result of diarrhea. Therefore, efforts should be made to ensure intervention taking such risk factors into consideration which eventually can turndown the consequence of the highest reported number of diarrhea-related infant death.

\section{Abbreviations}

AOR: Adjusted Odds Ratio; Cl: Confidence Interval; COR: Crude Odds Ratio; CSPro: Census Statistics Program; EIWR: Ethiopian Institute of Water Resources; ETB: Ethiopian Birr; L/C/d: Liters per capital per day; SD: Standard Deviation; SPSS: Statistical package for Social Sciences; WHO: World Health Organization.

\section{Acknowledgments}

We would like to special thank the West Harargehe zonal health department and the overall districts health offices (Chiro, Mieso, Gemechis, Tullo, Amibara and Awash Fentale) for their dedication and commitment in providing information and facilitate the study. We also extend our sincere thank for the study participants such as data collectors, supervisors and the respondents. Finally, our deepest gratitude and acknowledge goes to Addis Ababa University, EIWR and Care Ethiopia- West Hararghe Field Office for their technical and resources assistant.

\section{Authors reporting experiments on human data}

We confirm that all methods were carried out in accordance with relevant guidelines and regulations along with the approval.

\section{Authors' contributions}

S.M, A.W, D.G involved in conceptualization, data curation, format analysis, investigation, methodology, supervision, validation, visualization and editing. S.M contributed in project administration, resource, software and writingoriginal draft. All authors reviewed and approved the manuscript.

\section{Funding}

We have no received specific funding for this particular work.

\section{Availability of data and materials}

We confirm that all the relevant data are fully available. The dataset are accessible by contacting the corresponding author and provided upon a reasonable request.

\section{Declarations}

\section{Ethics approval and consent to participate}

Ethical approval to conduct the study was received from Ethics Review Board of Addis Ababa University - Ethiopian Water Resource Institute and also ethical clearance was provided by the research ethics committee of Oromia Regional Health Bureau. Before the study begins, official permission was secured from each study district administrative as well as health offices. Informed consent from each study subjects were obtained after clear and adequate explanation of the objectives and purpose of the study were provided using the participant's information sheet. Personal data, in particular name, geographical and contact information about the respondent is kept and be encrypted to protect privacy and ensure confidentiality.

\section{Consent for publication}

Not applicable.

\section{Competing interests}

We have no competing interests exist.

\section{Author details}

${ }^{1}$ Ethiopian Institute of Water Resources, Addis Ababa University, Addis Ababa, Ethiopia. ${ }^{2}$ School of Public Health, College of Health Sciences, Addis Ababa University, Addis Ababa, Ethiopia. ${ }^{3}$ Department of Molecular and Cell Biology, University of Connecticut, Storrs, CT 06269, USA.

Received: 25 November 2020 Accepted: 27 January 2022

Published online: 18 February 2022

\section{References}

1. Humphreys EH, Smith NM, Azman H, McLeod D, Rutherford GW. Prevention of diarrhoea in children with HIV infection or exposure to maternal HIV infection. Cochrane Database System Review PubMed. 2010; https:// doi.org/10.1002/14651858.CD008563.

2. Nelson R. Diarrhea remains leading cause of global mortality and morbidity. Infectious Disease Advisor. 2018; Available from: https://www.infec tiousdiseaseadvisor.com.

3. Will S. Diarrhea Still One of the World's Leading Cause of Death: PassportHealth; 2018. Available from: https://www.passporthealthusa.com.

4. Troeger C, Colombara DV, Rao PC, et al. Global disability-adjusted life-year estimates of long-term health burden and undernutrition attributable to diarrhoeal diseases in children younger than 5 years. Lancet Global Health. 2018;6(3):e255-69. https://doi.org/10.1016/S2214-109X(18) 30045-7.

5. Oria R, Pinkerton R, Lima AAM, Guerrant RL. In: Preedy VR, Watson RR, editors. Handbook of Disease Burdens and Quality of Life Measures: Springer New York; 2010. https://doi.org/10.1007/978-0-387-78665-0_69.

6. World Health Organization. Updates fact sheet on Diarrhoeal diseases. Geneva: World Health Organization; 2017. Available from: https://commu nitymedicine4asses.com.

7. Dadonaite B, Ritchie H, Roser M. Diarrheal Diseases. Our World in Data. 2018. Available from: https://ourworldindata.org/diarrheal-diseases.

8. World Health Organization. Global Health Estimates 2020: Deaths by Cause, Age, Sex, by Country and by Region, 2000-2019. Geneva: World Health Organization; 2020.

9. Karambu S, Matiru V, Kiptoo M, Oundo J. Characterization and factors associated with diarrhoeal diseases caused by enteric bacterial pathogens among children aged five years and below attending Igembe District hospital, Kenya. The Pan African Medical Journal. 2013;16. Available from: https://www.ncbi.nlm.nih.gov/pmc/articles/PMC3932116/.

10. World Health Organization. The world health report. Geneva, World Health Organization; 2002. Available from: https://apps.who.int/iris/bitst ream/handle/10665/42510/WHR_2002.pdf.

11. Roth GA, Abate D, Abate KH, Abay SM, Abbafati C, Abbasi N, et al. Global, regional, and national age-sex-specific mortality for 282 causes of death in 195 countries and territories, 1980-2017: A systematic analysis for the global burden of disease study 2017. Lancet. 2018;392(10159):1736-88.

12. Troeger C, Blacker BF, Khalil IA, Rao PC, Cao S, Zimsen SR, et al. Estimates of the global, regional, and national morbidity, mortality, and aetiologies of diarrhoea in 195 countries: a systematic analysis for the global burden of disease study 2016. Lancet Infectious Disease. 2018;18(11):1211-28.

13. Troeger C, Forouzanfar M, Rao PC, Khalil I, Brown A, Reiner RC, et al. Estimates of global, regional, and national morbidity, mortality, and aetiologies of diarrhoeal diseases: a systematic analysis for the global burden of disease study 2015. Lancet Infectious Disease. 2017;17(9):909-48.

14. Parashar UD, Kilgore PE, Holman RC, Clarke MJ, Bresee JS, Glass RI. Diarrheal mortality in US infants: influence of birth weight on risk factors for death. Archives of Pediatrics Adolescent Medicine. 1998;152(1):47-51. https://doi.org/10.1001/archpedi.152.1.47. 
15. World Health Organization, Maternal and Child Epidemiology Estimation Group (MCEE). Child causes of death, by Country and by Region, 20002016. Geneva: World Health Organization; 2018. Available from: http:// apps.who.int/gho/data/node.main.ChildMort?lang=en.

16. Central Statistical Agency (CSA) [Ethiopia] and ICF. Ethiopia Demographic and Health Survey 2016. Addis Ababa, Ethiopia, and Rockville, Maryland, USA: CSA and ICF; 2016.

17. Takele K, Zewotir T, Ndanguza D. Risk factors of morbidity among children under age five in Ethiopia. BMC Public Health. 2019;19(1):942.

18. Melese B, Paulos W, Astawesegn FH, Gelgelu TB. Prevalence of diarrheal diseases and associated factors among under-five children in Dale District, Sidama zone, southern Ethiopia: A cross-sectional study. BMC Public Health. 2019;19(1):1235.

19. Deribew A, Tessema GA, Deribe K, Melaku YA, Lakew Y, Amare AT, et al. Trends, causes, and risk factors of mortality among children under 5 in Ethiopia, 1990-2013: findings from the global burden of disease study 2013. Population Health Metrics. 2016;14(1):42.

20. Black RE, Morris SS, Bryce J. Where and why are 10 million children dying every year? Lancet. 2003;361(9376):2226-34. https://doi.org/10.1016/ S0140-6736(03)13779-8.

21. United Nation Children's Fund, World Health Organization. Diarrhoea: Why children are still dying and what can be done. New york: United Nations Children's Fund; 2009.

22. Centers for Disease Control and Prevention. Global Diarrhea Burden: Global Water, Sanitation and Hygiene. US department of Health and Human services, Centers for Disease Control and Prevention; 2015. Available from: https://www.cdc.gov/healthywater/global/diarrhea-burden.html.

23. United Nation Children's Fund. Diarrhoeal disease:United Nation Children's Fund data; 2018. Available from: https://data.unicef.org/topic/ child-health/diarrhoeal-disease/.

24. United Nation Children's Fund, World Health Organization. The basics Diarrhoea: why children are still dying and what can be done - prevention and treatment measures. The United Nations Children's Fund and World Health Organization; 2009; p. 1-68.

25. Peter H. Dirty Water: Estimated Deaths from Water-Related Diseases 2000-2020. Pacific Institute for studies in development, Environment, and security; 2002.

26. Levine MM, Nasrin D, Acacio S, et al. Diarrhoeal disease and subsequent risk of death in infants and children residing in low-income and middleincome countries: analysis of the GEMS case-control study and 12-month GEMS-1A follow-on study. The lancet Global Health. 2019. https://doi.org/ 10.1016/S2214-109X(19)30541-8.

27. Centers for Disease Control and Prevention. The Management of Acute Diarrhea in Children: Oral Rehydration, Maintenance, and Nutritional Therapy. Morbidity and Mortality Weekly Report (MMWR). 1992;41 (No. RR-16). Available from: https://www.cdc.gov/mmwr/preview/mmwrh tml/00018677.htm.

28. Bowen A, Agboatwalla M, Luby S, Tobery T, Ayers T, Hoekstra RM. Association between intensive handwashing promotion and child development in Karachi, Pakistan: a cluster randomized controlled trial. Archives of Pediatrics and Adolescent Medicine. 2012;166(11):1037-44.

29. Bartram J, Cairncross S. Hygiene, sanitation, and water: forgotten foundations of health. PLoS Med. 2010;7(11):e1000367.

30. Victora CG, et al. Water supply, sanitation and housing in relation to the risk of infant mortality from Diarrhoea. International Journal of Epidemiology. 1988;17:651-4.

31. Cheng J, Schuster-Wallace $C$, Watt $S$, et al. An ecological quantification of the relationships between water, sanitation and infant, child, and maternal mortality. BioMed Central Environmental Health. 2012;11:4.

32. Gashaw D, et al. What factors aggravate prevalence of diarrhea among infants of 7-12 months in southern Ethiopia? Insight Medical Publishing Group. 2017;25(5):321-5.

33. Ethiopian Population Census Commission. Summary and statistical report of the 2007 population and housing census. Addis Ababa, Ethiopia: 2008.

34. Anouk Z. The Weather and Climate in Ethiopia. TripSavvy; 2020. Available from: https://www.tripsavvy.com/ethiopia-weather-and-average-tempe ratures-4071422.

35. World Health Organization, United Nation Children's Fund. Core questions on drinking-water and sanitation for household surveys. Joint Monitoring Programme (JMP); 2006. Available from: https://apps.who.int/ iris/handle/10665/43489.
36. Ethiopian Ministry of Water, irrigation and electric. Second growth and transformation National Plan for the water supply and sanitation subsector (2015/16 - 2019/20), Addis Ababa, Ethiopia: 2015.

37. Centers for Disease Control and Prevention. The safe water system: Safe storage of drinking water. National center for emerging and zoonotic infectious diseases. Centers for Disease Control and Prevention; 2011. Available from http://www.cdc.gov/safewater.

38. Jm M, Dh E, Rc H, Je T, Ls C, Ud P. Risk factors for diarrhea-associated infant mortality in the United States, 2005-2007. Pediatric Infectious Disease Journal. 2012;31. Available from: https://pubmed.ncbi.nlm.nih.gov/22411 052/.

39. Mugo NS, Agho KE, Zwi AB, Damundu EY, Dibley MJ. Determinants of neonatal, infant and under-five mortality in a war-affected country: Analysis of the 2010 Household Health Survey in South Sudan. British Medical Journal Global Health. 2018;3(1). Available from: https://www. ncbi.nlm.nih.gov/pmc/articles/PMC5841513/.

40. Ezeh OK, Agho KE, Dibley MJ, Hall J, Page AN. The impact of water and sanitation on childhood mortality in Nigeria: evidence from demographic and health surveys, 2003-2013. International Journal of Environmental Research and Public Health. 2014;11(9):9256-72.

41. Gunther I, Schipper Y. Pumps, germs and storage: the impact of improved water containers on water quality and health. Pub Med. 2013; https://doi. org/10.1002/hec.2852.

42. Mohammed A, Nicolas $G$, Joachim $V$. The impact of drinking water quality and sanitation on child health: Evidence from rural Ethiopia. The journal of Development Studies. 2016;55:10(2193-2211).

43. Kremer Michael, Brandon Tan. Free provision of drinking water treatment and child survival: evidence from Kenya. American Economic Association; 2020. https://doi.org/10.1257/rct.5969-1.0.

44. Crump JA, Otieno PO, Slutsker L, Keswick BH, Rosen DH, Hoekstra RM, et al. Household based treatment of drinking water with flocculantdisinfectant for preventing diarrhoea in areas with turbid source water in rural western Kenya: cluster randomised controlled trial. British Medical Journal. 2005;331(7515):478.

45. Reynolds KA. Household water treatment: saving lives in the developing world. Water Conditioning and Purification International Magazine. 2006; Available from: https://wcponline.com/2006/04/14/household-watertreatment-saving-lives-developing-world/.

46. World Health Organization. Household water treatment and safe storage. Geneva, World Health Organization; 2019. Available from: http://www. who.int/water_sanitation_health/water-quality/household/en/.

47. Quick RE, Kimura A, Thevos A, et al. Diarrhea prevention through household-level water disinfection and safe storage in Zambia. American Journal of Tropical Medicine and Hygiene. 2002;66(5):584-9. https://doi. org/10.4269/ajtmh.2002.66.584.

48. Fink G, Günther I, Hill K. The effect of water and sanitation on child health: evidence from the demographic and health surveys 1986-2007. International Journal of Epidemiology. 2011;40(5):1196-204.

49. Alemu AM. To what extent does access to improved sanitation explain the observed differences in infant mortality in Africa?. African Journal of primary health care. Family Medicine. 2017;9(1).

50. Troeger CE, Khalil IA, Blacker BF, Biehl MH, Albertson SB, Zimsen SRM, et al. Quantifying risks and interventions that have affected the burden of diarrhoea among children younger than 5 years: an analysis of the global burden of disease study 2017. Lancet Infectious Disease. 2020;20(1):37-59.

51. Abou-Ali H. The effect of water and sanitation on child mortality in Egypt. Working Papers in Economics 112. University of Gothenburg, Department of Economics. 2003.

52. Getahun W, Adane M. Prevalence of acute diarrhea and water, sanitation, and hygiene (WASH) associated factors among children under five in Woldia town, Amhara region, northeastern Ethiopia. BMC Pediatrics. 2021;21(1):227.

53. Soboksa NE. Associations between improved water supply and sanitation usage and childhood diarrhea in Ethiopia: an analysis of the 2016 demographic and health survey. Environmental Health Insights. 2021;15:117863022110025.

54. Delelegn MW, Endalamaw A, Belay GM. Determinants of acute diarrhea among children under-five in Northeast Ethiopia: unmatched case-control study. Pediatric Health, Medicine and Therapeutics. 2020;11:323-33. 
55. Bawankule R, Singh A, Kumar K, Pedgaonkar S. Disposal of children's stools and its association with childhood diarrhea in India. BioMed Central Public Health. 2017;17.

56. Fayehun OA. Household environmental health hazards and child survival in sub-Saharan Africa. DHS working papers No. 74. Calverton, Maryland, USA: ICF Macro; 2010.

57. Brown J, Cairncross S, Ensink JHJ. Water, sanitation, hygiene and enteric infections in children. British Medical Journal. 2011. https://doi.org/10. 1136/archdischild-2011-301528.

58. Asfaha K, Alemseged F, Fisseha G, Haile K, Weldu M, Welehaweria N, et al. Determinants of childhood diarrhea in Medebay Zana District, Northwest Tigray, Ethiopia: a community based unmatched case-control study. BMC Pediatrics. 2018;18:120.

59. Solomon ET, Gari SR, Kloos H, Mengistie B. Diarrheal morbidity and predisposing factors among children under 5 years of age in rural East Ethiopia. Tropical Medicine and Health. 2020;48(1):66

60. United Nation-HABITAT. Solid Waste Management in the World's cities. United Nations human settlements Programme (UN-HABITAT), UNON Print Shop; 2009.

61. Ezzati $M$, et al. Selected major risk factors and global and regional burden of disease. Lancet. 2002. https://doi.org/10.1016/S0140-6736(02)11403-6.

62. Curtis V, Cairncross S. Effect of washing hands with soap on diarrhoea risk in the community: A systematic review. Lancet Infectious Disease. 2003;3(5):275-81. https://doi.org/10.1016/S1473-3099(03)00606-6.

63. Cairncross S, Hunt C, Boisson S, Bostoen K, Curtis V. Isaac CH Fung, wolf-Peter Schmidt, water, sanitation and hygiene for the prevention of diarrhoea. International Journal of Epidemiology. 2010;39(1):i193-205.

64. Oloruntoba OE. Hygiene and sanitation risk factors of diarrhoeal disease among under-five children in Ibadan, Nigeria. African Health Science. 2014;14(4). https://doi.org/10.4314/ahs.v14i4.32.

65. Dagne $\mathrm{H}$, Bogale L, Borcha M, et al. Hand washing practice at critical times and its associated factors among mothers of under five children in debark town, Northwest Ethiopia. Italian Journal of Pediatrics. 2019;45:120.

66. Waddington $\mathrm{H}$, Snilstveit B, White H, Fewtrell L. Water, Sanitation and Hygine interventions to combat Childhood diarrhoea in developing countries: A Systematic Review. International Initiative for Impact Evaluation. 2009.

\section{Publisher's Note}

Springer Nature remains neutral with regard to jurisdictional claims in published maps and institutional affiliations.

Ready to submit your research? Choose BMC and benefit from:

- fast, convenient online submission

- thorough peer review by experienced researchers in your field

- rapid publication on acceptance

- support for research data, including large and complex data types

- gold Open Access which fosters wider collaboration and increased citations

- maximum visibility for your research: over 100M website views per year

At BMC, research is always in progress.

Learn more biomedcentral.com/submissions 